\title{
Prediction of Atmospheric Corrosion -A Review
}

\author{
A.A.M.T. Adikari, R.G.N. De S. Munasinghe and S. Jayatileke
}

\begin{abstract}
Corrosion is defined as the degradation or loss of function of materials due to environmental effects. Corrosion has a huge impact on the economy of a country. This depends on the corrosive nature of environment of the country. Financial loss due to corrosion is inevitable but is controllable with the aid of proper corrosion management systems. Most of the countries use different methods for implementing corrosion management system in order to minimize the corrosion loss. In Sri Lanka the concern about corrosion is at a minimal stage but having a corrosion management system is becoming an essential requirement for future Sri Lanka. Implementation of corrosion management system has to be an all-country effort which has to be done with a much careful assessment of corrosive environment. There are several approaches for the assessment of corrosive environment and many researchers have been conducted all over the world. Evaluation of corrosivity as a function of environmental variables, which is known as corrosion modeling, and classification of corrosivity of atmosphere are widely used methods to assess the corrosive environment. In this paper the authors discuss about several existing environmental evaluation methods and models.
\end{abstract}

Keywords: Atmospheric corrosivity, Corrosion management system, Corrosion modeling, Corrosion Map.

\section{Introduction}

To great majority of the people corrosion means rust on iron. The reason may be, iron is the most frequently used metal throughout the human history and rust is the most common corrosion problem enhanced by them. Therefore nothing to be surprise that the term rust and corrosion are synonyms. But rust is a generic term used to describe different iron hydroxides and oxides, like $\mathrm{Fe}(\mathrm{OH})_{2}, \mathrm{Fe}(\mathrm{OH})_{3}$, $\mathrm{FeO}(\mathrm{OH}), \quad \mathrm{Fe}_{2} \mathrm{O}_{3} . \mathrm{H}_{2} \mathrm{O}$ that form when iron corrodes.

Historically corrosion has meant the destructive oxidation of metals but today engineering application include multitude of nonmetallic materials (Polymers, Ceramics, Semiconductors etc.). Therefore the term "corrosion" now means the degradation and loss of function by exposure to the operational environment of all materials. [1] In this report the term "corrosion" signifies to the corrosion of metallic materials.

Corrosion of metallic structures has a significant impact on a country's economy; therefore, the impact of corrosion is more often described in financial terms. Financial losses due to the corrosion have been assessed as a percentage of Gross National Product (GNP) by several countries. These studies show that the cost for the corrosion has been varied from $1-5 \%$ of GNP [2] .This is a significant amount to a developing country like Sri Lanka.

Most of the time corrosion cost implies only financial penalty, but the true cost of corrosion to the society are more than that and they are; Expensive and time waste (Prevention, maintenance), Waste of natural resources (replacement) and Inconvenience and loss of safety to the Society (Falling of bridges, towers, shut down of plants etc.) [3].

Eng. A.A.M.T Adikari, B.Sc. Eng. (Moratuwa), Research Engineer, Industrial Technology Institute.

Prof. R.G.N. De S. Munasinghe, Professor of Materials Engineering, Department of Materials Science and Engineering, University of Moratuwa,

Eng S. Jayathilake, B.Sc. Eng (Moratuwa, M. Eng (Japan), Senior Deputy Director. 
The total amount of impact depends on the nature of environment, level of corrosive agents in environment and the amount of use of metals especially, iron base alloys. The corrosion loss is comparatively higher in industrialized countries due to higher usage of metals and their atmosphere is more polluted.

The term corrosive environment includes the atmosphere, water, soil, acids, bases, inorganic solvents, molten salts and liquid metals.

Moisture which contains dissolved oxygen is the primary corrosive agent in atmospheric environment. Other substances, sulfur, nitrogen and chloride compounds and sodium chloride, may also contribute to this.

Water environments can also have a variety of compounds with corrosion characteristics. Fresh water normally contains dissolved oxygen, as well as other minerals several of which account for hardness. Seawater contains approximately3.5\% salt (predominantly sodium chloride) as well as some minerals and organic matter and it is generally more corrosive than fresh water.

Soils have a wide range of compositions and susceptibilities to corrosion. Compositional variables include moisture, oxygen, salt content, alkalinity and acidity as well as the presence of various forms of bacteria. [4]

\subsection{Theoretical aspect of corrosion}

Although there are many classification methods to identify the corrosion phenomena, for metallic materials the corrosion process is normally electrochemical, that is a chemical reaction in which there is a transfer of electrons from one chemical species to another, metal atoms characteristically lose or give up electron in what is called an Oxidation reaction.

For example Metal M Which has a valance of " $\mathrm{n}$ " oxidize according to the equation

$$
\text { M---------> } \mathrm{M}^{\mathrm{n}+}+\text { ne }
$$

The place which oxidation occurs is called as anode. The process the oxidation is sometime called as anodic reaction.

The electron generated due to the oxidation must be transferred to another place then the reaction occurs due to the transferred electron is called as reduction reaction, and the location at which the reduction occurs is called as cathode.
Therefore when anode and cathode are present a electrochemical reaction is formed and corrosion of a metal is occurred.

\section{Atmospheric corrosion}

Corrosion occurs in atmospheric environment referred as atmospheric corrosion is the most destructive type of corrosion that causes serious damage to metallic structures, vehicles and equipment. The corrosion damage mainly depends on exposure time (t) and some climatic factors like relative humidity (RH), temperature $(\mathrm{T})$, sulfur content, salinity (chloride), time of wetness (TOW) and the presence of some other pollutants such as air bone particles, nitrogen dioxide etc. [1] Corrosion Scientists and Engineers of many countries have carried out numerous amount of investigations on atmospheric corrosion. These studies reveal that the effect of corrosion is so serious that the annual cost of atmospheric corrosion is approximately half the total annual cost of all types of corrosion of metals. As previously mentioned the cost depends on many factors, for example industrialized countries have higher corrosion cost due to the usage of more metals and higher level of atmospheric pollution. Areas near to the coastal line also have higher corrosive environments.

Corrosion cost cannot be totally eliminated but could be minimized by using appropriate corrosion control techniques or corrosion management. Better corrosion management can be achieved through preventive strategies in non-technical and technical areas. For the implementation of preventive strategies against corrosion it is important to study the corrosive behavior of atmosphere. Internationally researches have conducted great amount of research to understand this phenomena and it is a very difficult task due to the complex nature of atmospheric corrosion. However, many approaches have been taken to understand the corrosivity of atmosphere, evaluation of corrosivity as a function of environmental variables, which is known as corrosion modeling, and classification of corrosivity of atmosphere. Those approaches can be considered as some popular method use to assess the corrosive environment. 


\section{Review of atmospheric corrosion Classification}

\subsection{European standard classification}

The European standard EN 12500-2000 [5] defines five categories of outdoor environment on the basis of the presence of corrosive agents in the air namely

Rural atmosphere: countryside and small towns, minor corrosive agent contamination (carbon dioxide, chlorides, artificial fertilizers). Urban atmosphere: densely populated areas, few industrial activities, medium corrosive agent contamination (sulfur dioxides)

Industrial atmosphere: intensive industrial activities, high corrosive agent contamination (sulfur dioxides);

Marine atmosphere: areas close to the sea, or internal zones strongly affected by airborne salinity. Corrosion effects are influenced by topographic conditions, prevailing wind direction.

Marine Industrial atmosphere: complex environment, areas close to both the sea and industrial districts, or internal zones located in the prevalent wind direction, Medium and/ or high corrosive agent contamination (sulfur dioxides, chlorides).

Due to its simplicity this has been the most commonly used method to classify the corrosive environment but the main drawback of this method is there is no clear boundary to distinguish each environment

\subsection{ISO Classification of atmospheric corrosivity}

A classification method has been introduced by International Standard Organization to assess the atmospheric corrosivity based on atmospheric variables. The standards describe methods to determine each of variables and respective rate of corrosion. Then these variables and corrosive atmospheres are categorized in different groups. [6,7,8] The classification of corrosive environments is present in Table 1, categorization of sulphur dioxide and chloride according to their deposition rate Table 2, and time of wetness (TOW) in Table 3.Following the categorization of these three key variables, the applicable ISO rate of corrosion $\left(\mathrm{g} / \mathrm{m}^{2}\right.$.year $)$ can be determined using the ISO chart (Table 4.). As an example in a particular atmospheric condition with sulphur dioxide deposition rate of $11-35 \mathrm{mg} / \mathrm{m}^{2}$.day $\left(\mathrm{P}_{1}\right.$ in Table 2$)$ and chloride deposition rate of $61-300 \mathrm{mg} / \mathrm{m}^{2}$.day $\left(S_{2}\right.$ in Table 3) with a time of wetness category
( $T_{4}$ in Table 3) the metal steel comes under corrosion category $\mathrm{C}_{4}$ (Table 1 ) which corrode with the rate of $401-650 \mathrm{~g} / \mathrm{m}^{2}$.year The table 5 shows relevant standards for this classification and measurements for rate of corrosion.

Although the ISO methodology represents a simple approach to corrosivity classification it has considered only three atmospheric variables, sulphur dioxide deposition rate chloride deposition rate and time of wetness (TOW).Therefore it is limited in its accuracy and precision. Since the atmospheric parameters determining the corrosivity classification do not include the effects of potentially important corrosive pollutants and impurities such as NOx, hydrogen sulfide, carbon dioxide, temperature, rainfall, wind speed etc..

Table 1 - ISO Classification of Corrosion rate after one year exposure predicted for different corrosivity classes

\begin{tabular}{ccccc}
\hline Corrosion category & $\begin{array}{c}\text { Steel, } \\
\mathrm{g} / \mathrm{m}^{2} \cdot \text { year }\end{array}$ & $\begin{array}{c}\text { Copper, } \\
\mathrm{g} / \mathrm{m}^{2} \cdot \text { year }\end{array}$ & $\begin{array}{c}\text { Aluminum, } \\
\mathrm{g} / \mathrm{m}^{2} \cdot \text { year }\end{array}$ & $\begin{array}{c}\text { Zinc, } \\
\mathrm{g} / \mathrm{m}^{2} \text { year }\end{array}$ \\
\hline$C_{1}$ & $\leq 10$ & $\leq 0.9$ & Negligible & $\leq 0.7$ \\
$C_{2}$ & $11-200$ & $0.9-5$ & $\leq 0.6$ & $0.7-5$ \\
$C_{3}$ & $201-400$ & $5-12$ & $0.6-2$ & $5-15$ \\
$C_{4}$ & $401-650$ & $12-25$ & $2-5$ & $15-30$ \\
$C_{5}$ & $651-1500$ & $25-50$ & $5-10$ & $30-60$ \\
\hline
\end{tabular}

Table 2 - ISO Classification of sulfur dioxide and chloride

\begin{tabular}{cccc}
\hline $\begin{array}{c}\text { Sulfur dioxide } \\
\text { category }\end{array}$ & $\begin{array}{l}\text { Sulfur dioxide } \\
\text { deposition rate, } \\
\mathrm{mg} / \mathrm{m}^{2} \text { day }\end{array}$ & $\begin{array}{c}\text { Chloride } \\
\text { category }\end{array}$ & $\begin{array}{c}\text { Chloride deposition rate, } \\
\mathrm{mg} / \mathrm{m}^{2} \cdot \text { day }\end{array}$ \\
\hline$P_{0}$ & $\leq 10$ & $S_{0}$ & $\leq 3$ \\
$P_{1}$ & $11-35$ & $S_{1}$ & $4-60$ \\
$P_{2}$ & $36-80$ & $S_{2}$ & $61-300$ \\
$P_{3}$ & $81-200$ & $S_{3}$ & $301-1500$ \\
\hline
\end{tabular}

Table 3 - ISO Classification of time of wetness

\begin{tabular}{|c|c|c|c|}
\hline Wetness category & $\begin{array}{c}\text { Time of wetness, } \\
\%\end{array}$ & $\begin{array}{l}\text { Time of wetness, } \\
\text { hours per year }\end{array}$ & $\begin{array}{c}\text { Examples of } \\
\text { environments }\end{array}$ \\
\hline$T_{1}$ & $<0.1$ & $<10$ & $\begin{array}{l}\text { Indoor with } \\
\text { climatic control }\end{array}$ \\
\hline$T_{2}$ & $0.1-3$ & $10-250$ & $\begin{array}{l}\text { Indoor without } \\
\text { climatic control }\end{array}$ \\
\hline$T_{3}$ & $3-30$ & $250-2500$ & $\begin{array}{l}\text { Outdoor in dry, cold } \\
\text { climates }\end{array}$ \\
\hline$T_{4}$ & $30-60$ & $2500-5500$ & $\begin{array}{l}\text { Outdoor in other } \\
\text { climates }\end{array}$ \\
\hline$T_{5}$ & $>60$ & $>5500$ & Damp climates \\
\hline
\end{tabular}

\subsection{Environmental Severity Index (ESI)}

This environmental severity index based on atmospheric parameters, has been developed by Michigan state university of USA for the maintenance management of structural aircraft systems. A Corrosion Damage Algorithm 
Table 4 - ISO Classification of Corrosivity and Pollutions levels

\begin{tabular}{|c|c|c|c|c|c|}
\hline TOW & $\mathrm{Cl}^{-}$ & $\mathrm{SO}_{2}$ & Steel & $\mathrm{Cu}$ and $\mathrm{Zn}$ & Al \\
\hline \multirow[t]{9}{*}{$T_{1}$} & \multirow[t]{3}{*}{$S_{0}$ or $S_{1}$} & $P_{1}$ & 1 & 1 & 1 \\
\hline & & $P_{2}$ & 1 & 1 & 1 \\
\hline & & $P_{3}$ & $1-2$ & 1 & 1 \\
\hline & \multirow{3}{*}{$S_{2}$} & $P_{1}$ & 1 & 1 & 2 \\
\hline & & $P_{2}$ & 1 & 1 & 2 \\
\hline & & $P_{3}$ & $1-2$ & $1-2$ & $2-3$ \\
\hline & \multirow[t]{3}{*}{$S_{3}$} & $P_{1}$ & $1-2$ & 1 & 2 \\
\hline & & $P_{2}$ & $1-2$ & $1-2$ & $2-3$ \\
\hline & & $P_{3}$ & 2 & 2 & 3 \\
\hline \multirow[t]{9}{*}{$T_{2}$} & \multirow[t]{3}{*}{$S_{0}$ or $S_{1}$} & $P_{1}$ & 1 & 1 & 1 \\
\hline & & $P_{2}$ & $1-2$ & $1-2$ & $1-2$ \\
\hline & & $P_{3}$ & 2 & 2 & $3-4$ \\
\hline & \multirow[t]{3}{*}{$S_{2}$} & $P_{1}$ & 2 & $1-2$ & $2-3$ \\
\hline & & $P_{2}$ & $2-3$ & 2 & $3-4$ \\
\hline & & $P_{3}$ & 3 & 3 & 4 \\
\hline & \multirow[t]{3}{*}{$S_{3}$} & $P_{1}$ & $3-4$ & 3 & 4 \\
\hline & & $P_{2}$ & $3-4$ & 3 & 4 \\
\hline & & $P_{3}$ & 4 & $3-4$ & 4 \\
\hline \multirow[t]{17}{*}{$T_{3}$} & \multirow[t]{3}{*}{$S_{0}$ or $S_{1}$} & $P_{1}$ & $2-3$ & 3 & 3 \\
\hline & & $P_{2}$ & $3-4$ & 3 & 3 \\
\hline & & $P_{3}$ & 4 & 3 & $3-4$ \\
\hline & \multirow[t]{3}{*}{$S_{2}$} & $P_{1}$ & $3-4$ & 3 & $3-4$ \\
\hline & & $P_{2}$ & $3-4$ & $3-4$ & 4 \\
\hline & & $P_{3}$ & $4-5$ & $3-4$ & $4-5$ \\
\hline & \multirow[t]{3}{*}{$S_{3}$} & $P_{1}$ & 4 & $3-4$ & 4 \\
\hline & & $P_{2}$ & $4-5$ & 4 & $4-5$ \\
\hline & & $P_{3}$ & 5 & 4 & 5 \\
\hline & \multirow[t]{2}{*}{$S_{0}$ or $S_{1}$} & $P_{1}$ & 3 & 3 & 3 \\
\hline & & $P_{2}$ & 4 & $3-4$ & $3-4$ \\
\hline & & & 4 & 4 & $3-4$ \\
\hline & & $P_{2}$ & 4 & 4 & 4 \\
\hline & & $P_{3}$ & 5 & 5 & 5 \\
\hline & $S_{3}$ & $P_{1}$ & 5 & 5 & 5 \\
\hline & & $P_{2}$ & 5 & 5 & 5 \\
\hline & & $P_{3}$ & 5 & 5 & 5 \\
\hline \multirow[t]{9}{*}{$T_{5}$} & \multirow{3}{*}{$S_{0}$ or $S_{1}$} & $P_{1}$ & $3-4$ & $3-4$ & 4 \\
\hline & & $P_{2}$ & $4-5$ & $4-5$ & $4-5$ \\
\hline & & $P_{3}$ & 5 & 5 & 5 \\
\hline & \multirow[t]{3}{*}{$S_{2}$} & $P_{1}$ & 5 & 5 & 5 \\
\hline & & $P_{2}$ & 5 & 5 & 5 \\
\hline & & $P_{3}$ & 5 & 5 & 5 \\
\hline & \multirow[t]{3}{*}{$s_{3}$} & $P_{1}$ & 5 & 5 & 5 \\
\hline & & $P_{2}$ & 5 & 5 & 5 \\
\hline & & $P_{3}$ & 5 & 5 & 5 \\
\hline
\end{tabular}

Numerical 1,2,3,4 \& 5 shown in table 4 represent the corrosivity categories $\mathrm{C} 1, \mathrm{C} 2, \mathrm{C} 3, \mathrm{C} 4$ \& $\mathrm{C} 5$ respectively

Table 5 - Relevant ISO Standard for atmospheric corrosion

\begin{tabular}{|c|c|}
\hline Standard & Title \\
\hline $\begin{array}{l}\text { ISO 9223: } \\
1992\end{array}$ & $\begin{array}{l}\text { Corrosivity of atmospheres - } \\
\text { Classification }\end{array}$ \\
\hline $\begin{array}{l}\text { ISO 9224: } \\
1992\end{array}$ & $\begin{array}{l}\text { Corrosivity of atmospheres - } \\
\text { Guiding values for the corrosivity } \\
\text { categories }\end{array}$ \\
\hline $\begin{array}{l}\text { ISO 9225: } \\
1992\end{array}$ & $\begin{array}{l}\text { Corrosivity of atmospheres - } \\
\text { Measurement of pollution }\end{array}$ \\
\hline $\begin{array}{l}\text { ISO 8407: } \\
1991\end{array}$ & $\begin{array}{l}\text { Corrosion of metals and alloys - } \\
\text { Removal of corrosion products } \\
\text { from corrosion test specimens }\end{array}$ \\
\hline
\end{tabular}

(CDA) has been proposed as a guide for anticipating extent of corrosion damage for planning maintenance operations. This classification scheme was developed primarily for uncoated aluminum, steel, titanium, and magnesium alloys exposed to the external atmosphere at ground level and applicable for other metals with appropriate modifications. The CDA algorithm is presented in Fig.1 and considers the distance to salt water, leading either to the very severe AA rating for close distance to seashore or a consideration of moisture factors. Following the moisture factors, pollutant concentrations are compared with values of working environmental Corrosion Standards (WECS). For example, a severe A rating would be given if any of the three pollutants considered in this scheme, that is, sulfur dioxide, total suspended particles (TSP), and ozone levels, would exceed the WECS values in combination with a high moisture factor. Considering the simplicity of the algorithms and simplifying assumptions in obtaining relevant environmental and maintenance data, the environmental corrosivity predicted from the CDA algorithm, was considered to be reasonable. However in this case also it is limited in its accuracy and precision since it has not considered other atmospheric parameters that determine the rate of corrosion.

Subsequent attempts to enhance the CDA algorithm by using the results obtained from broad based corrosion testing programs have failed to provide enough differentiation between moderately corrosive environments. $[9,10]$ 


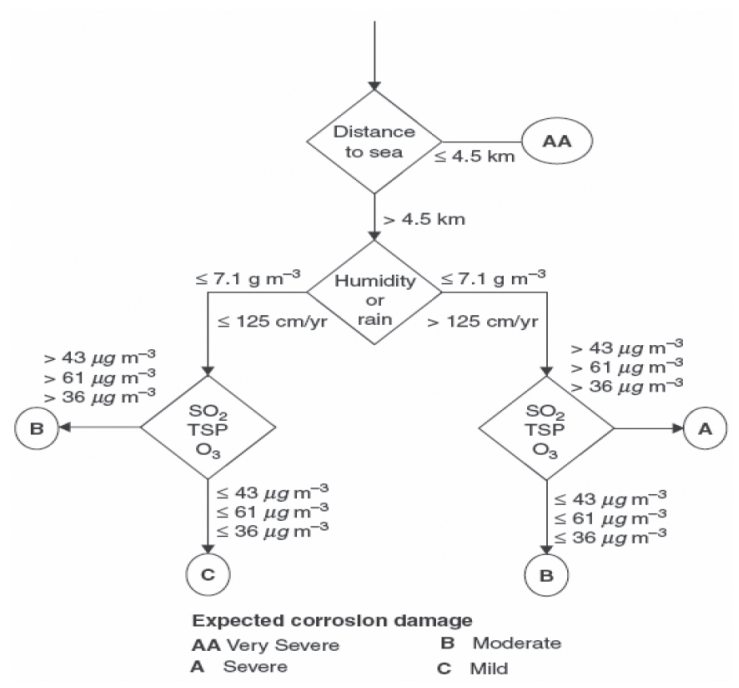

Figure 1 - The CDA algorithm for determining the corrosion severity for a given location

\subsection{Corrosion mapping}

Corrosion map is a powerful tools use in the field of corrosion engineering. A diagram that shows regional corrosion behavior is called as a corrosion map and it helps to understand the period of maintenance of major structures and measures to prevent corrosion.

Development of a corrosion map can be done with direct measurement of corrosion loss (rate of corrosion) by exposure test and prediction of corrosivity by atmospheric variables. The exposure of standard metal specimens at a grid of sites and the generation of computer contoured corrosion maps has been shown to be a sensitive and cost-effective means of differentiating geographical variations in corrosivity, which is a measure of the aggressiveness of the environment [10].Various countries have already developed their corrosion maps. Few examples are shown in Japan (Figure 2) Mexico (Figure 3) India (Figure 4).

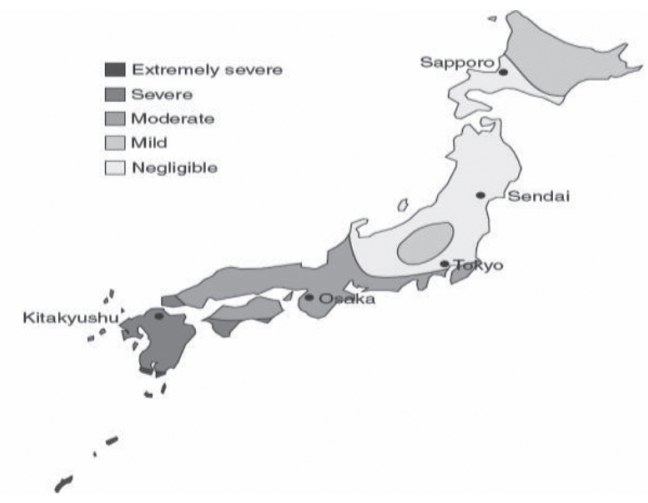

Figure 2 - Corrosion map Japan

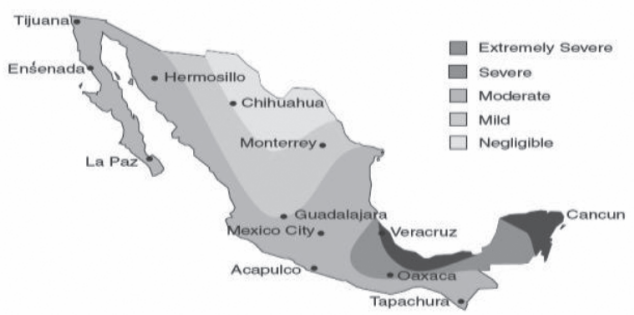

Figure 3 - Corrosion map Mexico

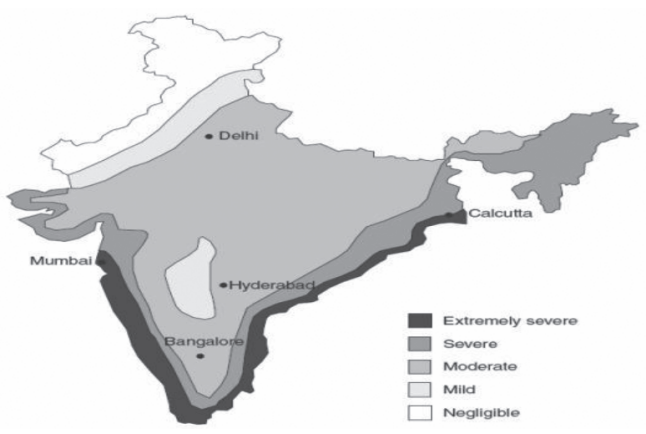

Figure 4 - Corrosion map India

\section{Corrosion modeling}

Models of materials degradation processes have been developed for a multitude of situations using a great variety of methodologies. For scientists and engineers who are developing materials, models have become an essential benchmarking element for the selection and life prediction associated with the introduction of new materials or processes. In fact, models are, in this context, an accepted method of representing current understandings of reality. Traditional models can be divided into two main categories: mathematical or theoretical models and statistical or empirical models. Mathematical models have the common characteristic that the response and predictor variables are assumed to be free of specification error and measurement uncertainty. Statistical models, on the other hand, are derived from data that are subject to various types of specification, observation, experimental, and/or measurement errors. In general terms, mathematical models can guide investigations, and statistical models are used to represent the results of these investigations

\subsection{Review of atmospheric corrosion prediction}

There are so many research activities conducted all over the world for the formulation of models for atmospheric corrosion. Many researchers have taken different approaches and obtained empirical 
relationships between corrosion rate and environmental parameters. One of the most common approaches is utilizing the linear bilogarithmic law (Eq-1) to describe atmospheric corrosion damage as a function of time on a mathematical basis since the atmospheric corrosion rate usually is not linear with time and the buildup of corrosion products often tends to reduce the corrosion rate over time. This law has shown to be applicable to different types of atmospheres (rural, marine, industrial etc.) and for a variety of alloys, such as carbon steels, weathering steels, galvanized steels, and aluminized steels. But It should be noted that not all alloy/environment combinations would follow this law. [1]

The linear bilogarithmic law mathematically can be expressed as

$$
\left\{\begin{array}{l}
\mathrm{C}=\mathrm{kt} \mathrm{k}^{\mathrm{n}} \\
\text { or } \\
\log _{10} \mathrm{C}=\log _{10} \mathrm{k}+\operatorname{nlog}_{10} \mathrm{t}
\end{array}\right.
$$

Where $C$ is the corrosion loss and $t$ is the exposure time. According to the linear bilogarithmic law, the atmospheric behavior of a specific material at a specific location can be defined by the two parameters $k$ and $n$. The initial corrosion rate, observed during the first year of exposure, is described by $k$, while $n$ is a measure of the long-term decrease in corrosion rate or passivation of materials which is directly dependent on the metal, the physicalchemical atmospheric conditions and the exposure conditions. This equation can be generalized to any location by defining the $\mathrm{k}$ and $\mathrm{n}$ values as a function of atmospheric variables.

$$
\begin{aligned}
& \left\{\mathrm{k}=\mathrm{f}\left(\mathrm{TOW}, \mathrm{Cl}^{-}, \mathrm{SO}_{2}, \mathrm{~T}, \text { etc.. }\right)\right. \\
& \left\{\mathrm{n}=\mathrm{F}\left(\mathrm{TOW}, \mathrm{Cl}^{-}, \mathrm{SO}_{2}, \mathrm{~T}, \text { etc.. }\right)\right.
\end{aligned}
$$

Where, temperature $(\mathrm{T})$, sulfur content $\left(\mathrm{SO}_{2}\right)$, salinity $\left(\mathrm{Cl}^{-}\right)$, time of wetness (TOW).

Then the relation between these parameters and atmospheric variables are determined by field exposure program and suitable statistical or software based method.

In some cases researchers have considered the rate of corrosion as a direct function of atmospheric variables.

$$
\left\{\mathrm{C}=\mathrm{f}\left(\mathrm{TOW}, \mathrm{Cl}^{-}, \mathrm{SO}_{2}, \mathrm{~T}, \text { etc.. }\right)\right.
$$

The relationship between corrosion rate and atmospheric variables is determined by field exposure program as in above case.

\subsection{Atmospheric corrosion models;}

As per the previously mentioned there are numerous approaches for corrosion modeling and following are some of examples for these approaches.

Japanese scientists analyzed the corrosion rate of carbon steel for one year in 43 exposure sites.[11]they have developed equations for each atmospheric condition

In urban or industrial sites, $\left\{\right.$ corrosion rate $(\mathrm{mdd})=4.15+0.88 \times \mathrm{T}\left({ }^{\circ} \mathrm{C}\right)$ $-0.073 \times \mathrm{RH}(\%)-0.032 \times$ rainfall (mm/month) $\left.+2.913 \times\left[\mathrm{Cl}^{-}\right]\left(\times 10^{-6}\right)+4.921 \times[\mathrm{SO} 2](\mathrm{mdd}) .(6)\right\}$

$\{$ In marine atmosphere, corrosion rate $(\mathrm{mdd})=5.61+2.754$ $\times\left[\mathrm{Cl}^{-}\right]\left(\times 10^{-6}\right)+6.155 \times[\mathrm{SO} 2](\mathrm{mdd})$.

*mdd: mg per square decimeter per day

A Cuban research group studied the atmospheric corrosion of non ferrous metal under different atmospheric conditions in Cuba and they have considered a different approach. [12] The usual time of wetness (RH $80 \pm 100 \%)$ was divided in two parts. when the temperature is lower than $25^{\circ} \mathrm{C}$ and when it is higher up to $35^{\circ} \mathrm{C}$. In this way, three different times of wetness are considered. Time due to rain, time including rain, dew and fog, and time when evaporation of the electrolyte layer prevails (air temperature $>25^{\circ} \mathrm{C}$ ). It is a more quantitative step in studying the role of time of wetness. By considering that the average corrosion rate is influenced

Principally by the deposition rates of chloride and SO2, and adding the effect of cleansing of the metallic surface, the following model is proposed.

$\left\{\mathrm{C}=\mathrm{a}+\mathrm{b} \mathrm{Cl}^{-} \tau_{5-25}+\mathrm{c} \mathrm{Cl}^{-} \tau_{25-35}+\mathrm{d} \mathrm{SO}_{2} \tau_{5-25}+\right.$ $\mathrm{eSO}_{2} \tau_{25-35}+\mathrm{fCl}^{-} \tau_{\text {rain }}+\mathrm{g} \mathrm{SO}_{2} \tau_{\text {rain }}+$

$\mathrm{h} \mathrm{mm} \tau_{\text {rain, }}$

where $\mathrm{C}$ is the weight loss in $\mathrm{g} / \mathrm{m} 2$ during 6 , 12 and 18 months of exposure, $\mathrm{Cl}^{-}$is the deposition rate of chloride ions in $\mathrm{mg} / \mathrm{m}^{2}$ day, $\mathrm{SO}_{2}$ is the deposition rate of sulphur compounds in $\mathrm{mg} / \mathrm{m}^{2}$ day, $\tau_{\text {rain }}$ and $\mathrm{mm}$ are the time and millimeters of rainfall, respectively, 
$\tau_{5-25}$ and $\tau_{25-35}$ the time of wetness at temperatures of $5-25^{\circ} \mathrm{C}$ and $25-35^{\circ} \mathrm{C}$, respectively, when the $\mathrm{RH}$ is over $80 \%$. [12]. This model can be applicable for ferrous metal also.

A model has been developed by International Cooperative Program ICP group with the aim to generalize the corrosion loss over time for different environments, reporting the climate and pollutants variables as independent factors. These functions have been formulated for different metallic materials and are based on both long-term exposures and trend analysis based on repeated one-year measurements of exposure. The degradation of metal over time is expressed by means of mass loss (ML) as a function of climatic parameters (Rh; T), gaseous pollutants (SO2, O3) and precipitation parameters (Rain, $\mathrm{H}+\mathrm{Cl}-$ ) as reported as fallows . [13]

Weathering Steel

$\left\{\mathrm{ML}=34[\mathrm{SO} 2]^{0.33} \exp \{0.020 \mathrm{Rh}+\right.$

$\mathrm{f}(\mathrm{T})\} \mathrm{t}^{0.33}$

Zinc

$\left\{\mathrm{ML}=1.4[\mathrm{SO} 2]^{0.22} \exp \left\{0.018 \mathrm{Rh}+\mathrm{f}(\mathrm{T}) \mathrm{t}^{0.85}+\right.\right.$

0.029Rain $[\mathrm{H}+] \mathrm{t}$

Aluminum

$\left\{\mathrm{ML}=0.0021[\mathrm{SO} 2]^{0.23} \cdot \mathrm{Rh} \exp \{\mathrm{f}(\mathrm{T})\} \mathrm{t}^{1.2}+\right.$

$0.000023 \mathrm{Rain}\left[\mathrm{Cl}^{-}\right] \mathrm{t}$

Copper

$\left\{\mathrm{ML}=0.0027[\mathrm{SO} 2]^{0.32}[\mathrm{O} 3]^{0.79} \mathrm{Rh} \exp \{\mathrm{f}(\mathrm{T})\}^{0.78}+\right.$ 0.050Rain[H+] $\mathrm{t}^{0.89}$

where:

ML: Mass loss [g/m2], t: exposure time (years), Rh: Relative humidity (\%), T: average annual temperature $\left({ }^{\circ} \mathrm{C}\right), \mathrm{f}(\mathrm{T}): \mathrm{a}(\mathrm{T}-10)$ when $\mathrm{T}<10^{\circ} \mathrm{C}$, otherwise $\mathrm{b}(\mathrm{T}-10)$, with $\mathrm{a}$, b being constant values depending on the specific metal, $\mathrm{SO}_{2}$ : Sulfur dioxide concentration $(\mu \mathrm{g} / \mathrm{m} 3), \quad \mathrm{O}_{3}$ : ozone concentration $(\mu \mathrm{g} / \mathrm{m} 3)$; Rain: Average annual rainfall precipitation $(\mathrm{mm}), \mathrm{H}^{+}$: hydrogen ion concentration in precipitation $(\mathrm{mg} / \mathrm{L}), \mathrm{Cl}^{-}$: Chloride ion concentration in precipitation $(\mathrm{mg} / \mathrm{L})$.

Field exposure test conducted by a research group of Brazil obtained values for parameter $\mathrm{n}$ and $\mathrm{k}$ of Power law $\mathrm{C}=\mathrm{k} \mathrm{t}^{\mathrm{n}}$ (Table 4 ) with the following equations.

$\left\{\quad \frac{d c}{d t}=n k t^{n-1}\right.$

$$
\begin{aligned}
& \left\{n=1+0.477\left(\log \left(\frac{d C}{d t}\right)_{2}-\log \left(\frac{d C}{d t}\right)_{1}\right)\right. \\
& \left\{\mathrm{k}=\frac{1}{\mathrm{n}}\left(\frac{d C}{d t}\right)_{1}\right.
\end{aligned}
$$

Where $\left(\frac{d C}{d t}\right)_{1},\left(\frac{d C}{d t}\right)_{2}$ represent the first year and second year corrosion losses respectively. [14]

Table $\mathbf{6}$ - Values of $\mathbf{n}$ and $\mathbf{k}$

\begin{tabular}{|l|l|l|l|l|l|l|}
\hline \multirow{2}{*}{ location } & \multicolumn{2}{|l|}{$\begin{array}{l}\text { Low carbon } \\
\text { steel }\end{array}$} & \multicolumn{2}{l|}{ Copper } & \multicolumn{2}{l|}{ Aluminium } \\
\cline { 2 - 7 } & $\mathrm{n}$ & $\mathrm{k}$ & $\mathrm{n}$ & $\mathrm{k}$ & $\mathrm{n}$ & $\mathrm{k}$ \\
\hline 1 & 1.55 & 71.25 & 0.72 & 8.43 & 0.58 & 1.12 \\
2 & 0.86 & 22.13 & 1.12 & 2.88 & 1.02 & 0.17 \\
\hline
\end{tabular}

Research project conducted by group of Iberoamerican presented an Artificial Neural Network (ANN)-based solution methodology for modeling atmospheric corrosion processes from observed experimental values, and an ANN model developed using the cited methodology for the prediction of the corrosion rate of carbon steel in the context of the Iberoamerican Corrosion Map (MICAT) Project, [15] which includes seventy-two test sites in fourteen countries throughout Iberoamerica. Classical regression model also developed in the context of this study, $\mathrm{Fe}=\mathrm{b} 0+\mathrm{Cl}^{-}\left(\mathrm{b}_{1}+\mathrm{b}_{2} \times \mathrm{p}+\mathrm{b}_{3} \times \mathrm{RH}\right)+\mathrm{b}_{4} \times \mathrm{TOW} \times \mathrm{SO} 2$

With $b_{0}=6.8124, \quad b_{1}=1.6907, \quad b_{2}=0.0004$, $b_{3}=0.0242$, and $b_{4}=2.2817$.

A research conducted by Klinesmith Scientist University of Maryland, USA developed a model for the atmospheric corrosion of carbon steel, zinc, copper and aluminum, taking into account the effects of four environmental variables (TOW; sulfur dioxide, salinity and temperature).(Ref) The general form of the degradation model is as follows:

$$
\begin{aligned}
& \left\{Y=A t^{B}\left(\frac{\mathrm{TOW}}{\mathrm{C}}\right)^{\mathrm{D}}\left(1+\frac{\left[\mathrm{SO}_{2}\right]}{\mathrm{E}}\right)^{\mathrm{F}}\left(1+\frac{[\mathrm{Cl}]}{\mathrm{G}}\right)^{\mathrm{H}} \mathrm{e}^{\mathrm{J}\left(\mathrm{T}+\mathrm{T}_{0}\right)}\right. \\
& \mathrm{C}=3800, \mathrm{E}=25, \mathrm{G}=50, \mathrm{~T}_{0}=20
\end{aligned}
$$

Where $\mathrm{y}=$ corrosion loss $(\mu \mathrm{m}) ; \mathrm{t}=$ exposure time (years); TOW = time-of-wetness (h/year); $\mathrm{SO} 2$ = sulfur dioxide concentration $\left(\mu \mathrm{g} / \mathrm{m}^{3}\right) ; \mathrm{Cl}$ is chloride deposition rate $\left(\mathrm{mg} / \mathrm{m}^{2} /\right.$ day $) ; \mathrm{T}=$ air temperature $\left({ }^{\circ} \mathrm{C}\right)$; and coefficient of equation are given below.[16] 
Table 7 - Coefficient of Equation 16

\begin{tabular}{lccccccc}
\hline & & \multicolumn{5}{c}{ Equation coefficients } \\
\cline { 3 - 8 } Materials & $\begin{array}{c}\text { Types of } \\
\text { specimens }\end{array}$ & $\mathrm{A}$ & $\mathrm{B}$ & $\mathrm{D}$ & $\mathrm{F}$ & $\mathrm{H}$ & $\mathrm{J}$ \\
\hline $\mathrm{CS}$ & Flat & 13.4 & 0.98 & 0.46 & 0.62 & 0.34 & 0.016 \\
$\mathrm{CS}$ & Helix & 19.7 & 0.05 & 0.46 & 0.62 & 0.34 & 0.016 \\
$\mathrm{Z}$ & Flat & 0.16 & 0.36 & 0.24 & 0.82 & 0.44 & 0.05 \\
$\mathrm{Z}$ & Helix & 0.26 & 0.05 & 0.24 & 0.82 & 0.44 & 0.05 \\
$\mathrm{C}$ & Flat & 0.46 & 0.15 & 0.02 & 0.38 & 0.46 & 0.02 \\
$\mathrm{C}$ & Helix & 0.78 & 0.22 & 0.02 & 0.38 & 0.46 & 0.02 \\
$\mathrm{~A}$ & Flat & 0.094 & 0.05 & 0.23 & 1.14 & 0.42 & 0.01 \\
$\mathrm{~A}$ & Helix & 0.27 & 0.05 & 0.23 & 1.14 & 0.42 & 0.01 \\
\hline Note: $\mathrm{CS}=$ carbon steel; $\mathrm{Z}=$ zinc; $\mathrm{C}=$ copper; and $\mathrm{A}=$ aluminum.
\end{tabular}

\section{Discussion}

Basically, a model is considered to be a representation of some object, behavior, or system that one wants to understand. Thus the purpose of a corrosion model is to predict an outcome. As such, a model can test or express a theoretical hypothesis in order to increase understanding of phenomenon. Models are useful only if they are validated and provide reasonable outcomes so that predictions can be tested. This will strongly depend on the relevance and accuracy of the data collected the level of understanding of the key parameters, and the observed knowledge.

The validity of a model rests not only on its fit to empirical observations but also on its ability to extrapolate to situations or data beyond those originally described in the model. Once validated, corrosion models can support a variety of analyses, such as estimating the required interval between maintenance and repair actions, gauging the effectiveness of various corrosion mitigation approaches, aiding in the selection of materials and coatings, and performing sensitivity analysis regarding the basic assumptions

In this framework, models are particularly valuable tools to gain knowledge and insight relatively quickly for assessing difficult, complex corrosion problems. It is challenging to predict the result when the environment varies dynamically in its corrosion potential. In Sri Lanka corrosion receives very little attention in engineering design; more often we use some other countries designs for our purposes. It has been occurred many corrosion failures of structures due to non compatibility of these designs to our environment but many corrosion problems can be solved at the design stage. For this purpose the understanding, knowledge and research on corrosion in Sri Lanka is becoming an essential requirement.
Furthermore the author is conducting research to find out effect of different Sri Lankan environmental conditions on corrosion of steel. And finally find out a suitable atmospheric corrosion model.

\section{References}

1. Roberg., Pierre, R., Hand book of corrosion engineering, New York, 2000, 58P,pp6669,pp84-85.

2. http://corrosion-doctors.org/WhyStudy/Strategic-Impact.htm , Visited , 7th June 2012.

3. Trethewey, K. R., Chamberlain, J., Corrosion for Students of Science and Engineering, New York , 1988, 5P

4. William, D., Callister, J. R., Fundamentals of Materials Science and Engineering, University of Utah , 2000, P S-229

5. EN 12500, Corrosion Likelihood in Atmospheric Environment, European Committee for Standardization (CEN), Brussels, Belgium, 2000.

6. International standard organization, ISO 9223 - Corrosion of metals and alloys corrosiovity of atmospheres Classification.

7. International standard organization, ISO 9224 - Corrosivity of atmospheres- guiding values for the corrosivity categories.

8. International standard organization, ISO 9225 - Corrosivity of atmospheresmeasurement of pollutions.

9. Summitt, R., Fink. F, T., "PACER LIME: An Environmental Corrosion Severity Classification System," AFWAL-TR-804102 Part I, AD AIOO 496 Air Force Wright Aeronautical Laboratories, WrightPatterson AFB OH, 1980. p 48

10. Pierre, R., Roberge., Corrosion Engineering principal and practice, New York, 2008, 358P.

11. Winston, R. R., Uhling's Corrosion Handbook, New York, 2005, 580P.

12. Antonio, R., Mendoza, Francisco, Corvo, "Outdoor and indoor atmospheric corrosion of non ferrous metal", J. Corrosion Science, Vol 42, 2000, PP 11231147.,

13. Kucera, V., Mapping Effects on materials in Manual Mapping Critical Load, ICP Materials Coordination Centre, Stockholm, Sweden, 2004, Available online: http://icpmapping.org (accessed on 1 December 2004). 
14. Elaine, D. K., Ramón, S. C. P., Luiz, A., Yuri, C. D. L., Gabriel, P. P., Souza D., Lázaris, J., “Artificial neural network corrosion modeling for metals in an equatorial climate" , J. Corrosion Science, Vol 51, 2009, pp 2266-2278.,

15. Salvador, Pintosa., Nestor, V., Queipoa, OladisTroconis., deRincoÂnb., Alvaro RincoÂnb., Manuel Morcilloc, Artificial neural network modeling of atmospheric corrosion in the MICAT project

16. Klinesmith, D. E., McCuen, R., Albrecht, P., " Effect of environmental condition on corrosion rate", J. Materials in Civil Engineering., ASCE, Vol. 19, February, 2007, pp. 121-129. 
